\title{
Differences Between The Pathogenicity Of Edwardsiella tarda And Aeromonas hydrophila Through Feed On The Survival Rate Of African Catfish (Clarias gariepinus) Fry
}

\author{
Kusnadi \\ Balai KIPM Jakarta II, Tanjung Priok, Indonesia \\ Nainggolan Armen \\ Major Aquaculture, Faculty of Fisheries and Marine Science, \\ University of Satya Negara Indonesia Jakarta \\ Lestira Yudha \\ Major Aquaculture, Faculty of Fisheries and Marine Science, \\ University of Satya Negara Indonesia Jakarta
}

\begin{abstract}
African catfish (Clarias gariepinus) is an important commodity in freshwater fish cultivation and is popular in Indonesia. The bacteria Aeromonas hydrophila and Edwardsiella tarda are bacteria that are dangerous to freshwater cultivation. This study aimed to discover the difference in the pathogenicity of Aeromonas hydrophila and Edwardsiella tarda through feed on the survival of African catfish fry. The study employed a Completely Randomized Design with 3 treatments and 3 replications: treatment A (exposed to Edwardsiella tarda through feed), B (exposed to Aeromonas hydrophila through feed), and $\mathrm{K} / \mathrm{control}$ (administration of feed without bacteria). The feed was administered ad libitum, the observation was conducted for 25 days, and the fish were kept in 9 aquariums at a seeding density of 100 individuals/aquarium (32L capacity). The observation parameters consisted of clinical signs, mortality, body weight increase, feed consumption rate, histopathological assessments, and water quality measurements. The results of the study revealed that Aeromonas hydrophila had a more significant effect on the survival rate of African catfish fry compared to Edwardsiella tarda (treatment A). The highest mortality in the test fish was demonstrated by treatment B (feed with Aeromonas hydrophila, $88 \%$ mortality). Treatment A (feed with Edwardsiella tarda) had a mortality rate of $68 \%$ and treatment $\mathrm{K}$ (without the addition of bacteria) had a mortality rate of $11 \%$.
\end{abstract}

Keywords: African catfish (Clarias gariepinus), Aeromonas hydrophila, Edwardsiella tarda, pathogenicity.

\section{INTRODUCTION}

African catfish can be cultivated in relatively high densities and the intensive feed administration have caused fish farmers many problems, especially related to diseases. An organism that most often causes disease in catfish is Edwardsiella tarda (Sari et al. 2014). Edwardsiella tarda is a pathogenic bacteria which causes Edwardsiellosis Putrefactive Emphysematous Diseases of Catfish (EPDC) and Red Pest (Ratnawati, 2013 in Meidiza et al. 2017).

Fish that are infected by the Edwardsiella tarda demonstrate changes in behavior and morphology and exhibit slow swimming (Setiowati et al., 2014). Furthermore, Firma et al. 
2012 reported that the bacteria Edwardsiella tarda could infect internal organs which include the liver, spleen, and kidneys. Jun et al. 2010 reported that the metabolic processes in the body would become disrupted if the liver is exposed to the infectious agent.

Besides being caused by the bacteria Edwardsiella tarda, disease in catfish could also be caused by other pathogenic organisms such as Aeromonas hydrophila. According to Hidayat et al. 2015, one of the diseases that most often occurs catfish is infection by Aeromonas hydrophila. Fish infected by these bacteria would undergo changes in its body, especially in the thorax, abdomen, and base of fins. The bacteria Aeromonas hydrophila could cause immense economic losses, even in well-maintained ponds, leading to massive mortality in the fish. The aquaculture of catfish is often disrupted by the Motile Aeromonas Septicaemia (MAS) disease which is commonly known as the red fin disease caused by infection by Aeromonas hydrophila.

There were three main elements in this study pertaining to pathogenicity which are the main focus, first, the bacteria Aeromonas hydrophila and Edwardsiella tarda as the target bacteria, second, feed as a medium for infection, and, third, catfish as the host. The first element was the bacteria Edwardsiella tarda and Aeromonas hydrophila which according to the Fishery and Marine Affairs Minister's Regulation KP number 81 Year 2015 are no longer classified as Fish Quarantine Pest and Disease (HPIK (Hama Penyakit Ikan Karantina)). The second element was feed, which according to the Decision of the Head of BKIPM number 99 year 2017 that fish feed (pellets) and the like are classified as Fish Pest and Disease Carrying Media whose entry and exit or traffic are regulated according to the laws in effect. The third element was catfish which according to the data from the Directorate General of Cultivation, Ministry of Fisheries and Marine Affairs in 2017 had a production of 1.8 million tons or increased $131.7 \%$ from the previous year's yield. This number was beyond the Fisheries and Marine Affairs Ministry target which was 1.3 million tons. In line with these, the author, as whose main responsibility is a Fish Pest and Disease Controller (Pengendali Hama and Penyakit Ikan (PHPI)), felt interested in conducting a study about the three elements mentioned above.

This study was aimed to discover the difference in the pathogenicity of E. tarda and $A$. hydrophila through feed on the survival of African catfish (Clarias gariepinus) fry.

\section{MATERIAL AND METHODS}

This study was conducted for 45 days, from February ${ }^{12}$ to March $^{28} 2018$. It was done in the African catfish farms in Pabuaran Village, Kemang Parung Bogor Sub-district, West Java. Laboratory tests were conducted at the Fish Quarantine Inspection Agency Jakarta II (Balai KIPM Jakarta II), Jl. Swasembada Timur XIII number 64 Tanjung Priok, North Jakarta.

The equipment employed in this study was 9 aquariums with $50 \mathrm{~cm} \times 40 \mathrm{~cm} \times 40 \mathrm{~cm}$ (dimensions of length $\mathrm{x}$ width $\mathrm{x}$ height, volume 32 liters), aerator sets, water quality measuring equipment (Horriba water quality checker), $1 \mathrm{ml}$ syringes, an analytical scale, a dissecting set, Petri dishes, test tubes, an autoclave, an oven, a magnetic stirrers, Bunsen burners, inoculation loops, a laminar air flow, incubator, microscopes, Erlenmeyer flasks, beaker glasses, measuring glasses, a vortex mixer, plastic trays, mortars, and other supporting equipment such as stationery, activity forms for the study, and documentation tools.

The materials used were test fish: African catfish (Clarias gariepinus) fry $4-5 \mathrm{~cm}$ long which originated from fish farmers in Parung Bogor numbering 1,000 individuals. The bacterial isolates for Edwardsiella tarda (NCIMB 2056) and Aeromonas hydrophila (ATCC 35654 PK 5) obtained from Balai Uji Standard Karantina Ikan Pengendalian Mutu dan Keamanan Hasil Perikanan (BUSKIPM), biochemical assay materials, fresh water, water quality testing 
materials, a set of materials for Gram staining (crystal violet, Lugol iodine, 95\% alcohol, and safranin), materials for biochemical assays for identifying Edwardsiella tarda and Aeromonas hydrophila $\left(\mathrm{H}_{2} \mathrm{O}_{2}\right.$, oxidase test, Kovacs, Motility Indole Ornithine, Lysine Iron Agar), Oxidase Fermentation medium, Tryptic Soy Iron Agar, MRVP medium, TCBS medium, glucose, maltose, sucrose, lactose, sorbitol, arabinose, mannitol, et cetera, and disposable equipment such as tissues, gloves, masks, and distilled water. The commercial catfish fry feed (floating type) with a size appropriate for the fry's mouth size used was Prima Feed floating feed PF 1,000 produced by PT Matahari Sakti.

The study was designed in two research phases, the Preliminary Study and the Main Study. The steps for the preliminary study consisted of: testing of the test fish, the feed to be used, water medium, and testing of the isolates, the revirulence test, determination of the dosage, testing for bacterial inhibition materials in the feed, and an acclimatization test. The main tests included observations of clinical assessments, mortality, biomass growth, feed efficiency, water quality, and histopathological tests. The general description of the steps in the preliminary study and the main study are presented in Figure 1. 


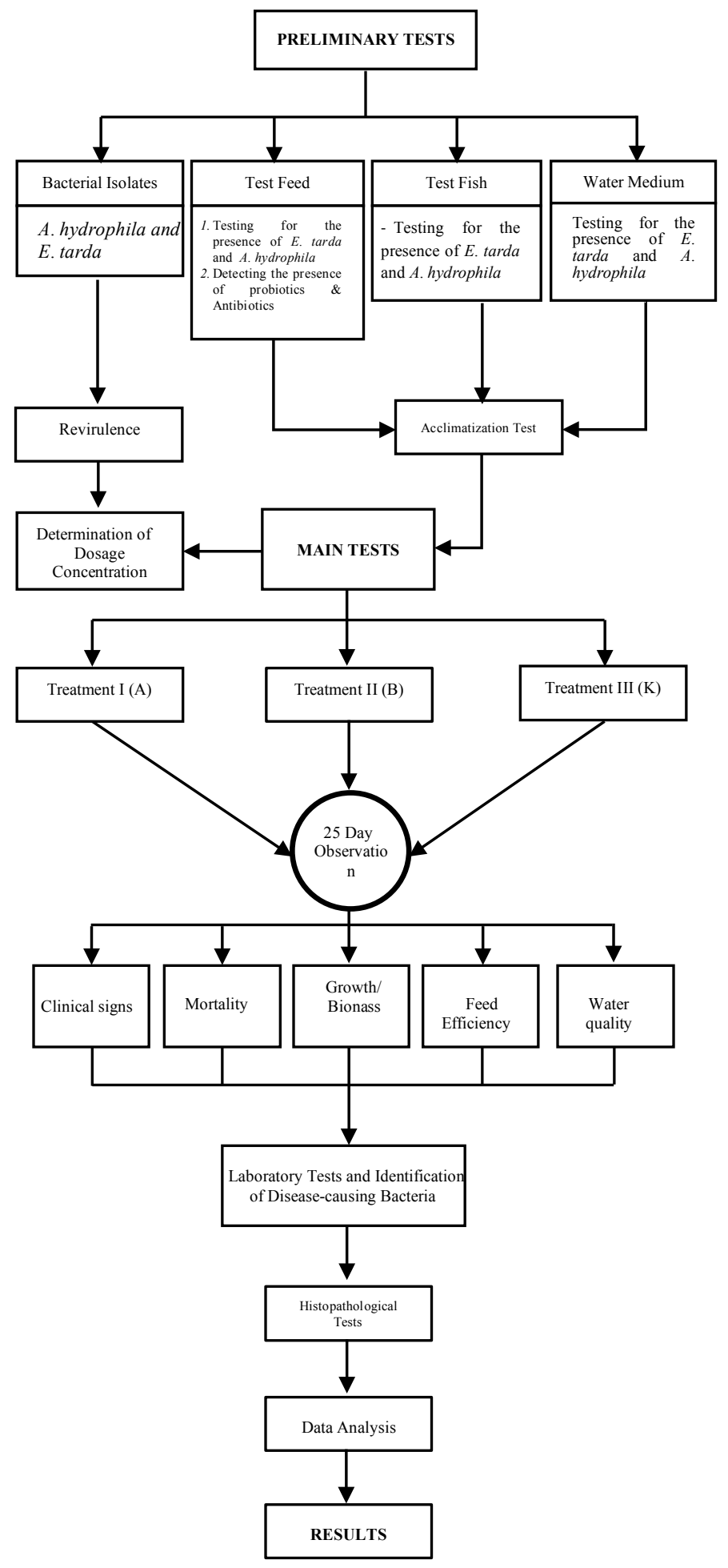

Figure 1. The study steps

\section{Preliminary Tests}

Cultivations and characteristic tests were conducted on the isolates from Balai Uji standar Karantina Ikan dan Pengendalian Mutu Hasil Perikanan (BUSKIPM) Jakarta as the source of isolates used in this study. After undergoing characteristic testing, the bacteria were cultured and enriched to be used as the material for the revirulence test.

The revirulence test was conducted on the isolates from BUSKIPM in order to reinstate the bacteria's virulence. The bacteria which were ATCC isolates were reinstated by infecting them to hosts or fish. The test parameter was the bacteria's ability to thrive and reproduce after 
incubation periods of 24, 36, 48, 60 and 72 hours. As the positive control, bacterial isolation from the control was conducted and it was cultured on a TSA cultivating medium and incubated for 24-36 hours at a temperature of $27{ }^{\circ} \mathrm{C}$. The dosage of bacteria injected into the fish was $0.1 \mathrm{ml}$ at a bacterial concentration of $10^{6} \mathrm{CFU} / \mathrm{ml}$ in $10 \mathrm{~cm}$ fish (Angka 2005).

To guarantee that the test fish used were in good health and not stressed under the study conditions, an acclimatization test was required. The parameters tested for in the acclimatization testing phase were mortality, behavior, feeding response, and any clinical signs that might develop. The experiment was conducted for seven days to assess whether the test fish had adapted to their environment and were not stressed. This test was also to assess whether or not the environment and experiment enclosures were appropriate for the lives of the test fish so that the results of the study conducted during the main testing would not be influenced by factors other than the treatments. The acclimatization test results were then compared to the main testing results for the control treatment (K). According to Kordi (2004), stress could cause the fish to go into shock and lose their appetites.

The determination of the dosage for bacterial concentration dosage to be mixed into the feed was conducted through an experimental method by observing the presence of bacteria in the intestines or digestive tract of the test fish after the 24-36 hour incubation period. The bacterial concentration used in this study was $10^{6} \mathrm{CFU} / \mathrm{ml}$ (Angka, 2005).

To see whether or not any inhibiting or microbe-killing factors were present in the feed used in the study, tests were conducted on the feed through biochemical assays. The purpose of these tests was to identify whether or not the feed contained any probiotics or antibiotics. Probiotics have an anti-microbial effect. The microbes in the probiotic compete with pathogens in the digestive tract, preventing the pathogens from utilizing the nutrients needed by the fish (Cruz et al., 2012). The testing parameter was the presence of an inhibition zone on the bacterial culture grown on an MH Agar medium with the powdered test-feed mixed in it and incubated for 24 hours at a temperature of $27-31^{\circ} \mathrm{C}$. The general method employed in this study is presented in Table 1 and The testing enclosure design is presented in Figure 2. 
Table 1. The general method in this study

\begin{tabular}{|c|c|c|c|}
\hline No & Variable & Testing method & Ref. \\
\hline & Treatment A & $\begin{array}{l}\text { Infection by the bacteria } \\
\text { Edwardsiella tarda }\end{array}$ & Experiment \\
\hline & Treatment B & $\begin{array}{l}\text { Infection by the bacteria } \\
\text { Aeromonas hydrophila }\end{array}$ & Experiment \\
\hline & $\begin{array}{l}\text { Treatment K } \\
\text { (control) }\end{array}$ & $\begin{array}{l}\text { Not infected with any } \\
\text { bacteria }\end{array}$ & RAL \\
\hline & Repetitions & $\begin{array}{l}\text { All the treatments were } \\
\text { repeated triplicate }\end{array}$ & \\
\hline & Test Fish & $\begin{array}{l}\text { African catfish } 4-5 \mathrm{~cm} \\
\text { long }\end{array}$ & Experiment \\
\hline & Testing medium & $\begin{array}{l}50 \times 40 \times 40 \mathrm{~cm} \\
\text { aquariums }\end{array}$ & Experiment \\
\hline & Seeding density & 3 individuals per liter & Bahtiar, 2007 \\
\hline & Population number & $\begin{array}{l}100 \text { individuals per } \\
\text { aquarium }\end{array}$ & \\
\hline & Feeding method & Ad libitum & \\
\hline & $\begin{array}{l}\text { Bacterial } \\
\text { concentration }\end{array}$ & $10^{6} \mathrm{CFU} / \mathrm{ml}$ & Angka 2005 \\
\hline & Observation length & 25 days & Experiment \\
\hline & $\begin{array}{l}\text { Bacteria } \\
\text { administration } \\
\text { technique }\end{array}$ & Day 1 to 5 & Taukhid,2008 \\
\hline & $\begin{array}{l}\text { Concentration } \\
\text { dosage with feed }\end{array}$ & $5 \mathrm{ml} / 10 \mathrm{gr}$ feed & Experiment \\
\hline
\end{tabular}

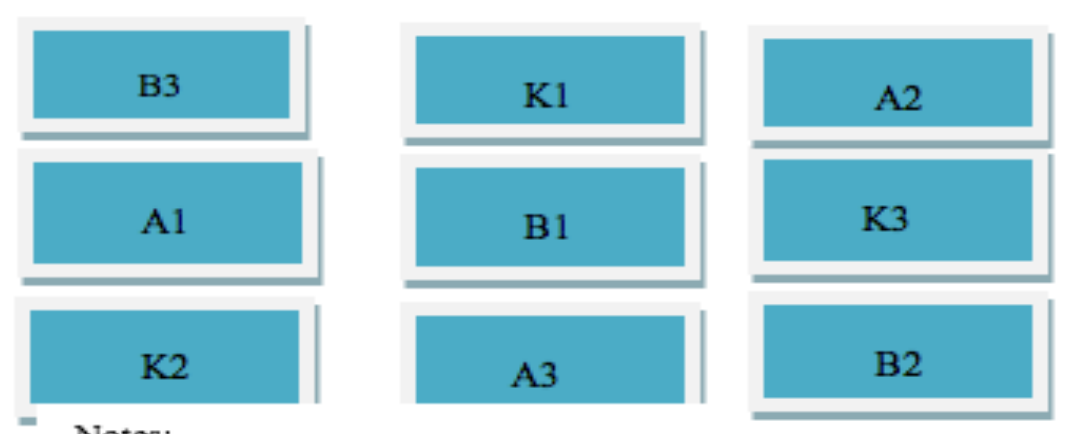
Notes:
A: Treatment with the bacteria Edwardsiella tarda
B: Treatment with the bacteria Aeromonas hydrophila
$\mathrm{K}$ : Treatment with the addition of sterile aquadest

Figure 2. The study design

\section{The Main Testing}

Observations of clinical signs were conducted by observing the test fish directly, consisting of the behavior, changes in color, appetite, and any physical symptoms demonstrated by fish as a result of the treatments. Clinical assessment was stated in the form of scores for the symptoms exhibited by the fish in each treatment.

Observations of mortality were conducted daily until the end of the study. The formula for calculating mortality (Effendi, 2003) is as follows:

\section{Mortality (\%) = The number of dead fish $\times 100 \%$ The fish population}


Increases in body weight were measured at the beginning, in the middle, and at the end of the study using a scale with an accuracy of $0.001 \mathrm{~g}$. The formula for weight calculation (Effendi, 2003) is:

\section{Weight calculation $\mathbf{G a}=\mathbf{W t}-$ Wo,}

Notes:

$\mathrm{Ga}=$ Absolute growth $(\mathrm{g})$

$\mathrm{Wt}=$ End interval weight $(\mathrm{g})$

Wo = Initial interval weight $(\mathrm{g})$

According to NCR (1993), the value for feed efficiency is calculated based on the difference between the fish's biomass at the end of the study with the fish's biomass at the beginning of the study divided by the weight of the feed administered using the following formula:

$$
\mathrm{FP}=\frac{w t-w o}{F} \times 100 \%
$$

Notes:

EP: Feed efficiency

Wt: The fish biomass weight at the end of the study $(\mathrm{g})$

Wo: The fish biomass weight at the beginning of the study

F: The amount of feed given

Fish that became ill or demonstrated clinical signs were subjected to laboratory tests in order to confirm whether the symptoms exhibited by the test fish were caused by the bacteria in the treatments. The test parameter was the presence of the bacteria in the liver, kidneys, and muscles.

Histopathological tests were conducted to discover the extent of the tissue damage in the flesh or muscles of the test fish caused by the bacterial infections.

To ensure that the water medium used in the study could support the lives of the test fish, the water quality was assessed on day 1 , day 3 , and so forth every three days until the experiment was concluded. The parameters tested were temperature, salinity, dissolved oxygen (DO), nitrites, nitrates, and ammonia.

Each of the treatments was repeated triplicate. To compare the effects of the treatment on the test fish's Survival Rate (SR), a statistical analysis in the form of the ANOVA test was conducted using the SPSS program version 16. If the test results between treatments were significantly different, a Least Significant Difference (LSD) follow-up test with a confidence level of $95 \%$ was conducted (Steel and Torrie, 2001).

\section{Preliminary Testing}

\section{RESULTS AND DISCUSSION}

The laboratory test result data on the test fish, water medium, and feed are presented in Table 2. 
Table 2. Laboratory test result data for the bacteria

\begin{tabular}{|l|l|c|c|c|}
\hline \multirow{2}{*}{ No } & \multicolumn{1}{|c|}{ Type of Sample } & $\begin{array}{c}\text { Edwardsiella } \\
\text { tarda }\end{array}$ & $\begin{array}{c}\text { Aeromonas } \\
\text { hydrophila }\end{array}$ & \multirow{2}{*}{ Result } \\
\cline { 3 - 4 } 2 & $\begin{array}{l}\text { Catfish fry samples } \\
\text { code A, B and K }\end{array}$ & - (negative) & - (negative) & $\begin{array}{c}\text { Not } \\
\text { detected }\end{array}$ \\
\hline 2 & $\begin{array}{l}\text { Floating pellet fish } \\
\text { feed samples }\end{array}$ & - (negative) & - (negative) & $\begin{array}{c}\text { Not } \\
\text { detected }\end{array}$ \\
\hline 3 & $\begin{array}{l}\text { Water medium } \\
\text { samples code A, B, K }\end{array}$ & - (negative) & - (negative) & $\begin{array}{c}\text { Not } \\
\text { detected }\end{array}$ \\
\hline
\end{tabular}

Based on the data in Table 2, the test results revealed that the test fish, water medium, and fish feed used in the study were free from Edwardsiella tarda and Aeromonas hydrophila.

The laboratory test result data pertaining to isolate number $168 \mathrm{~B}$ and $05 \mathrm{~B}$ are presented in Table 3.

Table 3. Results for the characteristic tests for E. tarda and hydrophila bacterial isolates

\begin{tabular}{|c|c|c|c|c|}
\hline \multirow[b]{2}{*}{ No } & \multirow[b]{2}{*}{ Type of Sample } & \multicolumn{2}{|c|}{ Bacteria tested } & \multirow{2}{*}{$\begin{array}{c}\text { Test } \\
\text { results }\end{array}$} \\
\hline & & $\begin{array}{c}\text { Edwardsiella } \\
\text { tarda }\end{array}$ & $\begin{array}{l}\text { Aeromonas } \\
\text { hydrophila }\end{array}$ & \\
\hline 1 & $\begin{array}{l}\text { Isolate code } \\
168 \mathrm{~B}\end{array}$ & $+($ positive $)$ & - (negative) & $\begin{array}{l}\text { E. tarda } \\
\text { detected }\end{array}$ \\
\hline 2 & $\begin{array}{l}\text { Isolate code } \\
05 \mathrm{~B}\end{array}$ & - - (negative) & $+($ positive $)$ & $\begin{array}{l}\text { A hydrophila } \\
\text { detected }\end{array}$ \\
\hline
\end{tabular}

Identification of the bacteria was conducted on the bacteria A. hydrophila ATCC 35654 PK 5 by culturing it on a selective medium for Aeromonas hydrophila, RS (Rimler Shots) medium, and Gram staining. The color of $A$. hydrophila colonies on the RS medium is yellow, while when stained with Gram staining the bacteria appeared to be short red (Gram-negative) rod-shapes (BSN 2009). Biochemical identification was conducted using a number of methods including the oxidase, catalase, TSIA, $\mathrm{H}_{2} \mathrm{~S}$, Gas, Motile, Indole, $\mathrm{O} / \mathrm{F}$, and citrate tests. The bacteria demonstrated the following characteristics: rod-shaped, classified as Gram-negative, while the biochemical assay results were oxidase positive, catalase positive, motility positive, indole positive, ornithine positive, Simmon's citrate fermentation negative, MR-VP negative, gelatine hydrolysis positive, methyl red positive, gas found, and did not produce $\mathrm{H}_{2} \mathrm{~S}$. The results for the identification were in line with the opinion by Holt et al. (1994).

The results of the biochemical identification of the E. tarda NCIMB 2056 isolate revealed that Edwardsiella tarda had the following characteristics: Gram-negative, circular colonies at a diameter of 0.5-0-1 mm, transparent and slightly cream-colored, pada on McConkey medium the bacteria grew well, were short rod-shaped, nonacid-fast, motile, produced $\mathrm{H}_{2} \mathrm{~S}$, produced gas when fermenting glucose, sucrose, lactose positive. This matched the description by Plump (1999) "the main characteristics of E. tarda are the motility and indole production in tryptone broth".

The results of the bacterial isolates from BUSKIPM showed that the two bacteria were identified as Edwarsiella tarda and Aeromonas hydrophila isolates. The bacteria were then isolated and cultured in TSA and TSB media and made into bacterial suspensions for use in the revirulence test.

The results for the revirulence test of the Edwardsiella tarda and Aeromonas hydrophila isolates are presented in Table 4. 
Table 4. The results of the revirulence test of the E.tarda and A. hydrophila isolates obtained from BUSKIPM.

\begin{tabular}{|c|c|c|c|c|c|c|}
\hline \multirow{2}{*}{$\begin{array}{l}\text { Revirulence } \\
\text { Test }\end{array}$} & \multirow{2}{*}{$\begin{array}{l}\text { Test } \\
\text { Fish }\end{array}$} & \multicolumn{5}{|c|}{ Incubation period (hours) } \\
\hline & & 24 & 36 & 48 & 60 & 72 \\
\hline \multirow[t]{5}{*}{ E.tarda } & 1 & Negative & & & & \\
\hline & 2 & & negative & & & \\
\hline & 3 & & & positive & & \\
\hline & 4 & & & & negative & \\
\hline & 5 & & & & & Positive \\
\hline Control(+) & $\begin{array}{l}\text { TSA } \\
\text { medium }\end{array}$ & positive & & & & \\
\hline \multirow[t]{5}{*}{ A.hydrophila } & 1 & negative & & & & \\
\hline & 2 & & positive & & & \\
\hline & 3 & & & positive & & \\
\hline & 4 & & & & negative & \\
\hline & 5 & & & & & Positive \\
\hline Control(+) & $\begin{array}{l}\text { TSA } \\
\text { medium }\end{array}$ & positive & & & & \\
\hline
\end{tabular}

Based on the results of the revirulence test presented in Table 4 above, the revirulence test for Edwardsiella tarda on the test fish positively identified the bacteria in test fish numbers 3 and 5 in the $48^{\text {th }}$ and $72^{\text {nd }}$ hour of incubation post injection. The bacteria were found in the kidneys and the digestive tract, while in fish numbers 1, 2 and 4, Edwardsiella tarda was not identified. The testing was conducted using biochemical assay methods to identify the types and characteristics in the laboratory. However, in treatment $\mathrm{K}$ which was the positive control, the bacteria thrived and reproduced well in the TSA medium in the $24^{\text {th }}$-hour post isolation. The results of the revirulence test for Aeromonas hydrophila revealed that the test fish identified as positive, having bacteria discovered in their kidneys and digestive tracts, were test fish numbers 2, 3 and 5, each at the 36th, 48th, and 60th hour, respectively. In the positive control, Aeromonas hydrophila thrived and reproduced in the TSA medium 24 hours post isolation.

The test fish that had the bacteria identified more quickly, at the 48th hour, was fish number 3 for Edwardsiella tarda and fish number 2 for Aeromonas hydrophila. Bacteria from fish number 2 (two) and 3 (three) were re-isolated onto TSA growth media and purified and enriched to then be made into a bacterial suspension which was used to expose the man-made feed for the main testing. According to Darmayasa (2008), pathogenic bacteria isolated from a number of fish body parts such as the liver, kidneys, and ulcerated or wounded skin, then isolated on TSA medium using the streak plate technique. The incubation period was 24 - 48 hours.

This was in line with the opinion by Hong et al. (2005) who reinjected E. tarda which was isolated from catfish in the same fish species in order to increase the virulence. Bacterial virulence needs to be increased because the metabolism of bacterial cells in vitro cultures could decrease after a certain length of time. Most bacteria would achieve optimum growth during the exponential phase and then the bacteria would enter a stationary phase during the incubation period up to 48 hours. This condition is related to the availability of nutrients and a suitable environment for the bacteria. The isolates above had been stored in a refrigerator in an inactive state at a temperature of $4{ }^{\circ} \mathrm{C}$ which could cause the enzymatic activity to decrease (Moat et al. 2002).

The results of the observation of the acclimatization test are presented in Table 5 below. 
Table 5. Results of the observation of the acclimatization Test.

\begin{tabular}{|l|l|l|}
\hline No & Testing Parameters & Observation Results \\
\hline 1. & Response to feed & Normal for all tanks \\
\hline 2. & $\begin{array}{l}\text { Response to the } \\
\text { environment }\end{array}$ & Normal for all tanks \\
\hline 3. & $\begin{array}{l}\text { Physical/morphological } \\
\text { changes }\end{array}$ & Not found in any tanks \\
\hline 4. & Growth & $\begin{array}{l}\text { Good/Normal for all } \\
\text { tanks }\end{array}$ \\
\hline 5. & Mortality & $\begin{array}{l}\text { Low, less than } 1 \% \text { in all } \\
\text { tanks }\end{array}$ \\
\hline
\end{tabular}

Based on the results of the acclimatization test in Table 5, it can be seen that all the test fish had adapted to the study environment; they did not experience stress or have a high mortality rate and did not exhibit clinical signs of sickness. Based on the results of the observation of the acclimatization test, the main study could be continued to the next phase. According to Kvitt (2004), "Healthy fish exhibit signs of active movement, good appetite, and show no physical changes". Furthermore, Ariati et a., (2013) stated that if one organ or part of the fish's body is disturbed, all the fish's tissues will also be disturbed. The disturbance in body tissues affects the working mechanism of the tissues, inhibiting the fish's growth. Based on the results of the acclimatization test, all of the test fish in each treatment were in good health and were not stressed. According to Mim (1987) and Supriyadi (1990), "Bacteria will enter easily and infect fish when the fish are under stress and weak."

The results for the determination test for the dosage of the bacteria added to the feed are presented in Table 6.

Table 6. The Observation results for the dosage determination test

\begin{tabular}{|c|c|c|c|c|c|c|}
\hline No & Treatment & $\begin{array}{l}\text { Dosage }(\mathrm{ml}) \\
10^{6} \mathrm{CFU} / \mathrm{ml}\end{array}$ & $\begin{array}{l}\text { Number of } \\
\text { test fish } \\
\text { (individuals) }\end{array}$ & $\begin{array}{l}\text { Incubation } \\
\text { period } \\
\text { (hours) }\end{array}$ & $\begin{array}{l}\text { Prevalence } \\
\text { (individuals) }\end{array}$ & $\begin{array}{l}\text { Best } \\
\text { dosage }\end{array}$ \\
\hline \multirow{3}{*}{1} & \multirow{3}{*}{$\begin{array}{l}\text { Edwardsiella } \\
\text { tarda }\end{array}$} & 0.05 & 10 & 36 & 0 & - \\
\hline & & 0.10 & 10 & 36 & 5 & - \\
\hline & & 0.20 & 10 & 36 & 9 & $\begin{array}{c}0.20 \mathrm{ml} / \\
\text { individual }\end{array}$ \\
\hline \multirow{3}{*}{2} & \multirow{3}{*}{$\begin{array}{l}\text { Aeromonas } \\
\text { hydrophila }\end{array}$} & 0.05 & 10 & 36 & 2 & - \\
\hline & & 0.10 & 10 & 36 & 4 & - \\
\hline & & 0.20 & 10 & 36 & 9 & $\begin{array}{c}0.20 \mathrm{ml} / \\
\text { individual }\end{array}$ \\
\hline
\end{tabular}

Based on the dosage determination test, the best dosage was demonstrated by the test with a dosage of $0.20 \mathrm{ml}$ per individual. The $0.20 \mathrm{ml}$ bacteria dosage added to the feed demonstrated the best results with a prevalence of $90 \%$. All the samples were tested and the bacteria were identified in the intestines or digestive organs. Based on the study conducted by Angka (2005), the dosage of bacteria which is lethal to $90 \%$ of the test fish in 96 hours is bacteria with a density of $10^{6} \mathrm{CFU} / \mathrm{ml}, 0.1 \mathrm{ml}$ inoculated to fish weighing 10 grams.

The results of the test for bacteria- inhibiting substances in the feed are presented in Table 7. 
Table 7. The results of the test for bacterial growth-inhibiting substances in the feed

\begin{tabular}{|c|l|l|l|}
\hline No & $\begin{array}{c}\text { Type of } \\
\text { bacteria }\end{array}$ & \multicolumn{1}{|c|}{ Sensitivity test } & $\begin{array}{l}\text { Biochemical assay } \\
\text { of the feed }\end{array}$ \\
\hline Edwardsiella & $\begin{array}{l}\text { An inhibition } \\
\text { zone was not } \\
\text { found around the } \\
\text { feed on MH } \\
\text { medium. }\end{array}$ & $\begin{array}{l}\text { Probiotic bacteria } \\
\text { (Bacillus sp) were } \\
\text { not detected }\end{array}$ \\
\hline 2. & $\begin{array}{l}\text { Aeromonas } \\
\text { hydrophila }\end{array}$ & $\begin{array}{l}\text { An inhibition } \\
\text { zone was not } \\
\text { found around the } \\
\text { feed on MH } \\
\text { medium. }\end{array}$ & $\begin{array}{l}\text { Probiotic bacteria } \\
\text { (Bacillus } \text { sp) were } \\
\text { not detected }\end{array}$ \\
\hline
\end{tabular}

Based on the observation of the laboratory results on the two types of feed, the biochemical test did not detect the presence of the probiotic bacteria Bacillus $s p$ and did not find any antibiotic substances. The two laboratory test results showed that there was no inhibition zone around the feed incubated at a temperature of $27^{\circ} \mathrm{C}$ placed on the bacterial cultures grown on MH agar media.

As a probiotic, Bacillus sp has been studied extensively because of its ability to adhere and to produce bacteriocin (an antimicrobial peptide) and immunostimulant (Barbosa et al., 2005). This strain has been proven to be effective as a commercial probiotic which could increase the production in aquaculture. In addition, Bacillus $s p$ has an added value as a probiotic because it can be stored in the form of spores (Hong et al., 2005). Furthermore, Yardimci and Yilmaz (2011) added that the higher the dosage of anti-bacteria used, the faster the bacterial cells would be deactivated.

\section{The Main Testing}

Observations were made of changes in the physical and morphological aspect of the test fish, the behavior, feeding response, signs of infection, and the onset of death in the test fish. The clinical signs were calculated using a scoring system to clarify the level of difference between treatments. The clinical sign scoring during the study is presented in Figure 3.

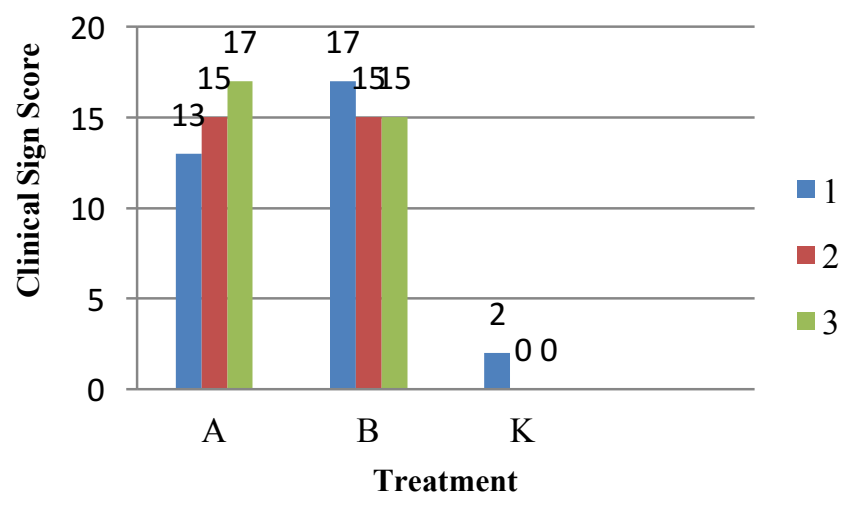

Notes: A = Clinical signs by Edwarsiella tarda

$\mathrm{B}=$ Clinical signs by Aeromonas hydrophila

$\mathrm{K}=$ Without Bacteria

Figure 3. A bar chart depicting the clinical signs in each treatment

The observation results of the clinical signs revealed that clinical signs were nearly the same height between treatment $A$ and treatment $B$, but were very different from treatment $\mathrm{K}$ (control), which had a very short bar, in other words, the fish did not exhibit any clinical signs. The figure above shows that exposure to Aeromonas hydrophila had almost the same effect on 
the emergence of clinical signs in the $4-5 \mathrm{~cm}$ long test African catfish (Clarias gariepinus) fry as exposure to Edwardsiella tarda during the study. Results of the observation revealed that exposure to Aeromonas hydrophila was slightly higher because the feeding response and onset of changes in body coloration were quicker, on day 5, while in the treatment with Edwardsiella tarda these signs emerged on day 8.

In treatment I (A1, A2, A3), the clinical signs observed were drooping in the fish, abnormal swimming, the presence of small, red wounds, and paleness. This was in line with the opinion of Meyer and Bullock (1973) who stated that Edwardsiella tarda infection in catfish caused small wounds $3-5 \mathrm{~mm}$ in diameter located posterolateral, appearing to be lacking in pigmentation and swollen.

In treatment II (B1, B2, B3) the onset of clinical signs was earlier than in treatment I, with clinical signs including pale skin, peeling skin, bleeding in the fins, and finally terminated by death on day 9. According to Mulia (2010), clinical signs that arose due to Aeromonas hydrophila infections include pale gills and physical abnormalities along with red spots (hemorrhages) on the dorsum and behind the operculum and posterior fin, an increased mucus production, ragged fins, and the emergence of white spots. The physical changes and clinical signs in the test fish are presented in Figure 4.

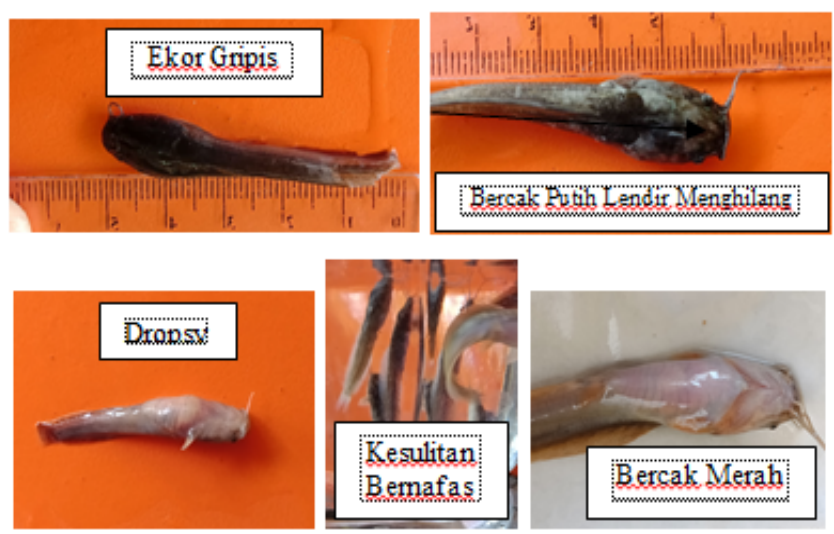

Figure 4. The clinical signs found in the test fish

In general, the clinical signs caused by Edwardsiella tarda and Aeromonas hydrophila were similar to the physical changes undergone by the test fish in this study. According to Kurniawan (2012), clinical signs of an infection by E. tarda are similar to those caused by Aeromonas hydrophila, in the form of small ulcers on the skin and damage to muscle tissue which is usually accompanied by the formation of gas which is trapped between damaged tissues (malodorous). Sick fish would lose control over the posterior half of their bodies, even though they would continue to feed. In fish, there can also be observed tissue damage in the form of a bulging or open ulcer in the anterior of the facial bone between the two eyes (hole in the head disease).

According to Hasyim and Galil (2012), test catfish infected with E. tarda cultures will exhibit very pronounced clinical signs from muscle necrosis, some of the organs turning white, and hemorrhage followed by the swelling of other infected body parts (dropsy), bleeding on the body, gills, and abdomen, and a frayed tail fin. According to Austin and Austin (1987), fish infected by Aeromonas hydrophila exhibit signs such as abnormal behavior, gasping on the water surface, loss of appetite, damage to the tail fin, skin dryness and roughness, bulging eyes, and a distended abdomen filled with reddish fluid. 
Kordi (2004) stated that in identifying or diagnosing fish diseases, having knowledge of the clinical signs is very important because it can help determine the cause.

Data from the observation results of the test fish mortality are presented in Figure 5.

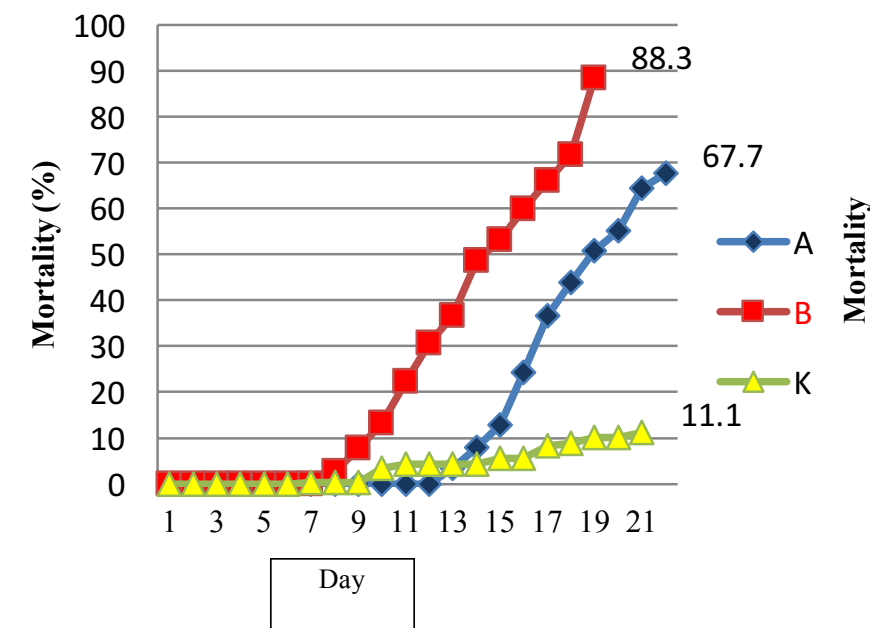

\footnotetext{
Notes: A = Mortality caused by Edwarsiella tarda

$\mathrm{B}=$ Mortality caused by Aeromonas hydrophila

$\mathrm{K}=$ Mortality without bacteria
}

Figure 5. The Mortality Rate in the Test Fish

Based on the results of the observation on mortality, the mortality level in treatment I (A1, A2, A3) ranged between 62 and $77 \%$ or an average of $68 \%$. In treatment II (B1, B2, B3), the test fish mortality ranged between 83 and $93 \%$ or an average of $88.3 \%$, and in treatment III (K1, $\mathrm{K} 2, \mathrm{~K} 3$, the test fish mortality rate was $10-13 \%$ or an average of $11.6 \%$.

There were differences between the mortality rates of test fish in the test fish during the study. The comparison between the mortality rates can be seen in more detail in Figure 6.

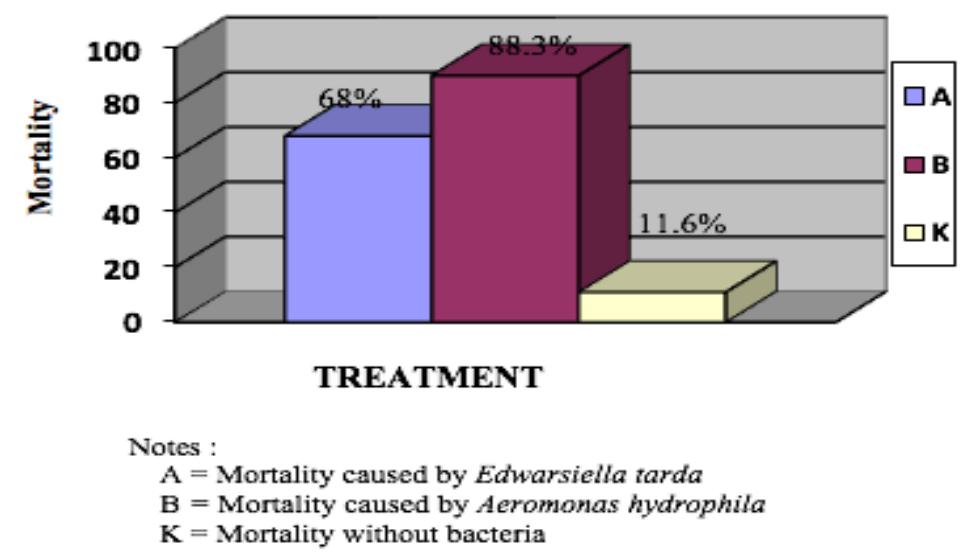

Figure 6. Comparison between the mortality rates in the test fish

The data collected revealed that the highest mortality was in the test fish in treatment B or in the treatment with the addition of Aeromonas hydrophila (88\%), while in treatment A with the addition of Edwardsiella tarda, the average mortality was $68 \%$. When compared to treatment $\mathrm{K}$ (Control) which did not have any bacteria added, the treatments with bacteria demonstrated higher mortality rates. 
Edwardsiellosis can cause up to $80 \%$ mortality in the wild population. In a study where Edwardsiella tarda was infected intraperitoneally in $5-10 \mathrm{~cm}$ catfish at a temperature of $27^{\circ} \mathrm{C}$, it was found to kill 4 out of fish in 10 days. The fish that die could exhibit bleeding around the head, operculum, and internal organs (Meyer \& Bolloc, 1973). Infections by Aeromonas hydrophila could cause outbreaks with high mortality rates (between 80-100\%) in a short time only, between one to two weeks (Holt et al., 1994).

According to Wahyuningrum (2010), $8.0 \times 10^{7} \mathrm{CFU} / \mathrm{ml}$ of Edwardsiella tarda could be deadly to up to $80 \%$ of the population in 10 days time; the dead fish exhibiting hemorrhages around the head, operculum, and internal organs. On the other hand, according to Angka (2005), catfish injected with $10^{6} \mathrm{CFU} / \mathrm{ml}$ Aeromonas hydrophila experienced inflammations and death exceeding $60 \%$. This was in line with the results of this study which revealed a $60-90 \%$ mortality rate in the test fish infected with the pathogenic within the 21-day study period.

The data from observation results of the weight and feed consumption rates in the test fish are presented in Figures 7 and 8.

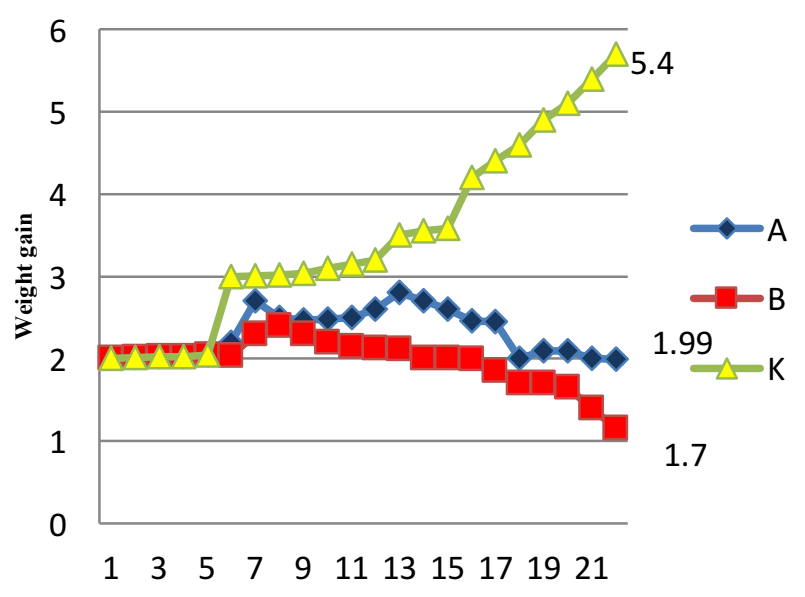

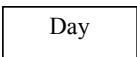

Notes: A $=$ Growth of fish exposed to Edwarsiella tarda

$\mathrm{B}=$ Growth of fish exposed to Aeromonas hydrophila

$\mathrm{K}=$ Growth of fish not exposed to bacteria
}

Figure 7. The Rate of Weight Gain in the Test Fish

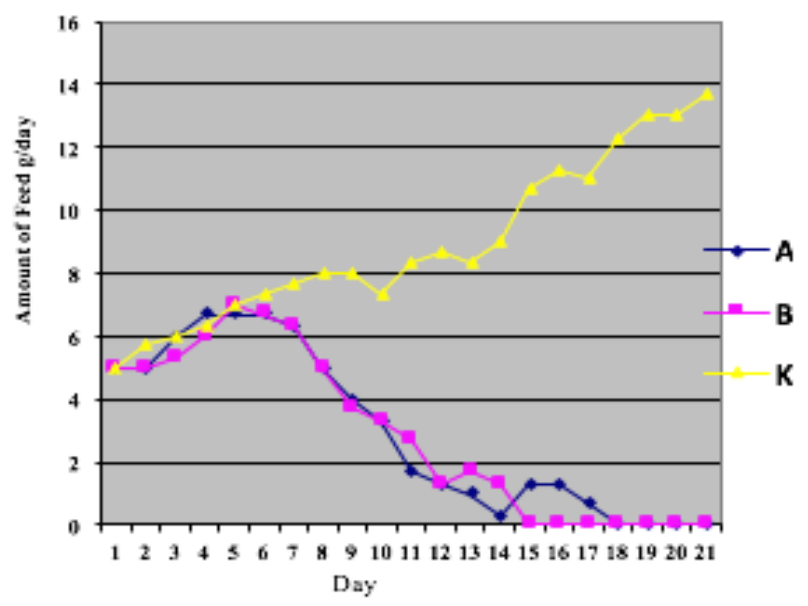

Notes: A - Fish feed consumption rate under the influence of Edwarsieila tarda B - Fish feed consumption rate under the influence of $A$. hydrophifo $\mathrm{K}-$ Fish feed consumption rate not under the influence of bacteria

Figure 8. The Daily Feed Consumption Rate for Each Treatment 
Based on Figures 7 and 8, it can be seen that the weight gain and the daily feed consumption are directly proportional. In treatment $\mathrm{K}$ (control), the increase in feed consumption was proportional to the increase in individual weight, whereas, in treatments $A$ and $B$, the decrease in feed consumption was proportional to the decrease in daily individual weight. This was because on day 7 the fish in treatments A and B began to exhibit clinical signs and a decrease in appetite, and on day 14 the fish had completely stopped feeding, leading to disruptions in their growth (the fish appeared thin and abnormal). This differed from treatment $\mathrm{K}$ where the individual weight continued to increase in proportion to the increased feed consumption and the lack of bacterial infections.

The individual weight gain changed each week. In treatments $\mathrm{A}$ and $\mathrm{B}$, the individual weight gains were almost the same, ranging between 0.5 and 0.6 , whereas in treatment $K$, the weight gain in week 1 reached 1.35 .

According to Ariati et al. (2013), the decrease in feed consumption and the protein digestibility will cause a decrease in the growth rate. If one of the fish's organs is disturbed, it will disturb all the tissues in the fish's body. The disruptions will affect the working mechanisms in the tissues, inhibiting the fish's growth.

The data from the laboratory tests on the test fish on days 7, 14 and 21 are presented in Table 8.

Table 8. The laboratory test results on the sample test fish during the rearing period in the study

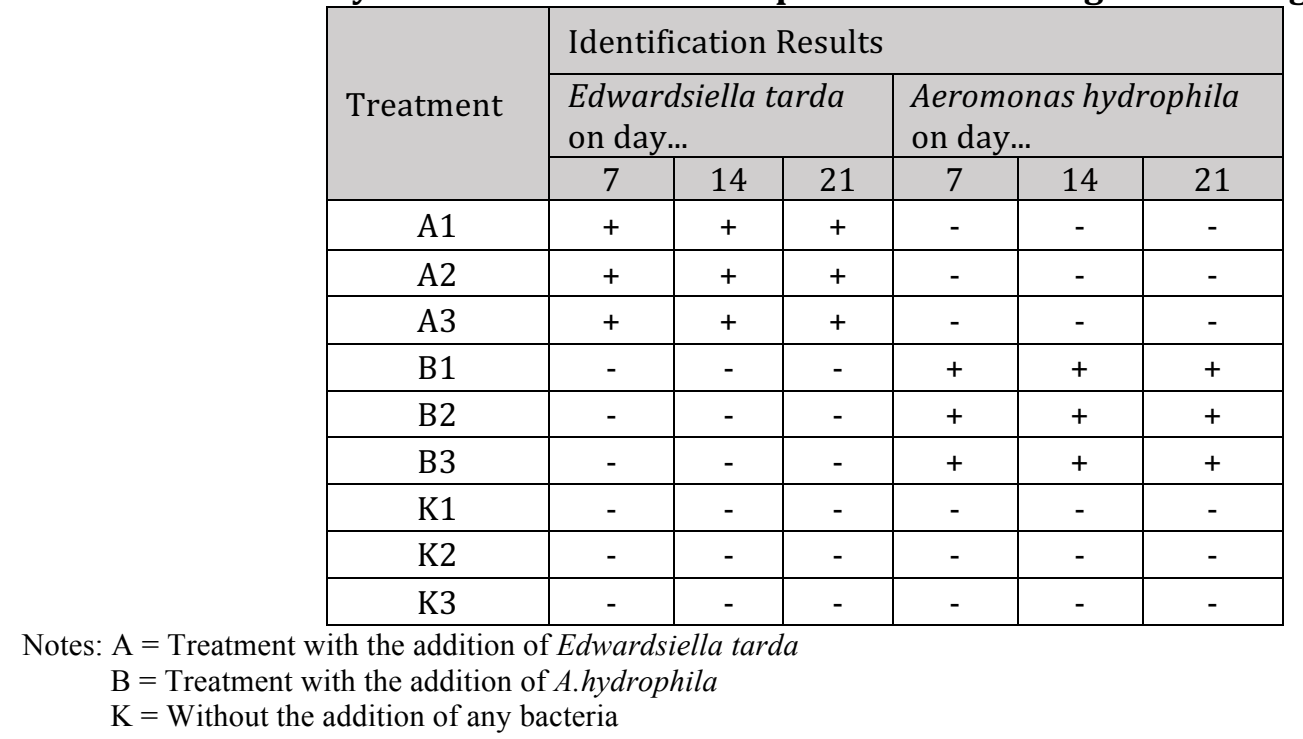

The data for laboratory tests on the test fish on dayxs 7, 14 and 21 revealed that in fish treated with treatments A1, A2 and A3 the bacteria Edwardsiella tarda were discovered. In the fish treated with treatments B1, B2, B3 the bacteria Aeromonas hydrophila were discovered. The testing was conducted by isolating the bacteria from the flesh and organs and identifying the bacteria using biochemical assays. On the other hand, in the fish treated with treatments K1, $\mathrm{K} 2$ and $\mathrm{K} 3$, the two bacteria were not discovered.

The biochemical identification results of the bacteria isolated from the fish in treatment I (A1, A2, A3) confirmed that the bacteria were Edwardsiella tarda, demonstrating the identifying characteristics such as Gram-negative, short rods, nonacid-fast, motile, produces $\mathrm{H}_{2} \mathrm{~S}$, produces gas during glucose fermentation, sucrose, and lactose positive. This was in line with Meidiza et 
al., (2017) who stated that the main characteristics of E. tarda are the motility and indole production in tryptone broth.

The biochemical identification results of the bacteria isolated from the fish in treatment II (B1, B2, B3) confirmed that the bacteria were Aeromonas hydrophila demonstrating the identifying characteristics such as Gram-negative with short-bacillus shape cells, motile, positive for oxidase enzyme and catalase enzyme production, oxidative and fermentative positive, and positive lactose fermentation. This was in line with the opinion of Sukenda et al., (2002).

Edwardsiella tarda infections on both various cultivated fish and fish living in open waters have been reported such as in catfish, eels, mullets, chinook salmon, tilapia, et cetera (Todar, 2002). According to Meyer and Bullock (1973), the species most often infected by Edwardsiella tarda are catfish and eels. This was also apparent in the laboratory test result data for the samples from treatment I (A1, A2, A3) which were positive for Edwardsiella tarda in all the samples tested. Therefore, the disease-causing bacterium in treatment A was Edwardsiella tarda. This was further supported by the data from the clinical assessment which revealed physical changes in the test fish which matched the physical changes caused by this particular bacteria, while the results in treatment B pointed toward Aeromonas hydrophila.

The E. tarda and A. hydrophila infections caused histopathological changes in the catfish during the experiment. These changes were visible in the liver (hepatopancreas), kidneys, pancreas, and spleen. In general, the histological changes in the catfish's liver and kidneys in every treatment were nearly the same in this experiment.

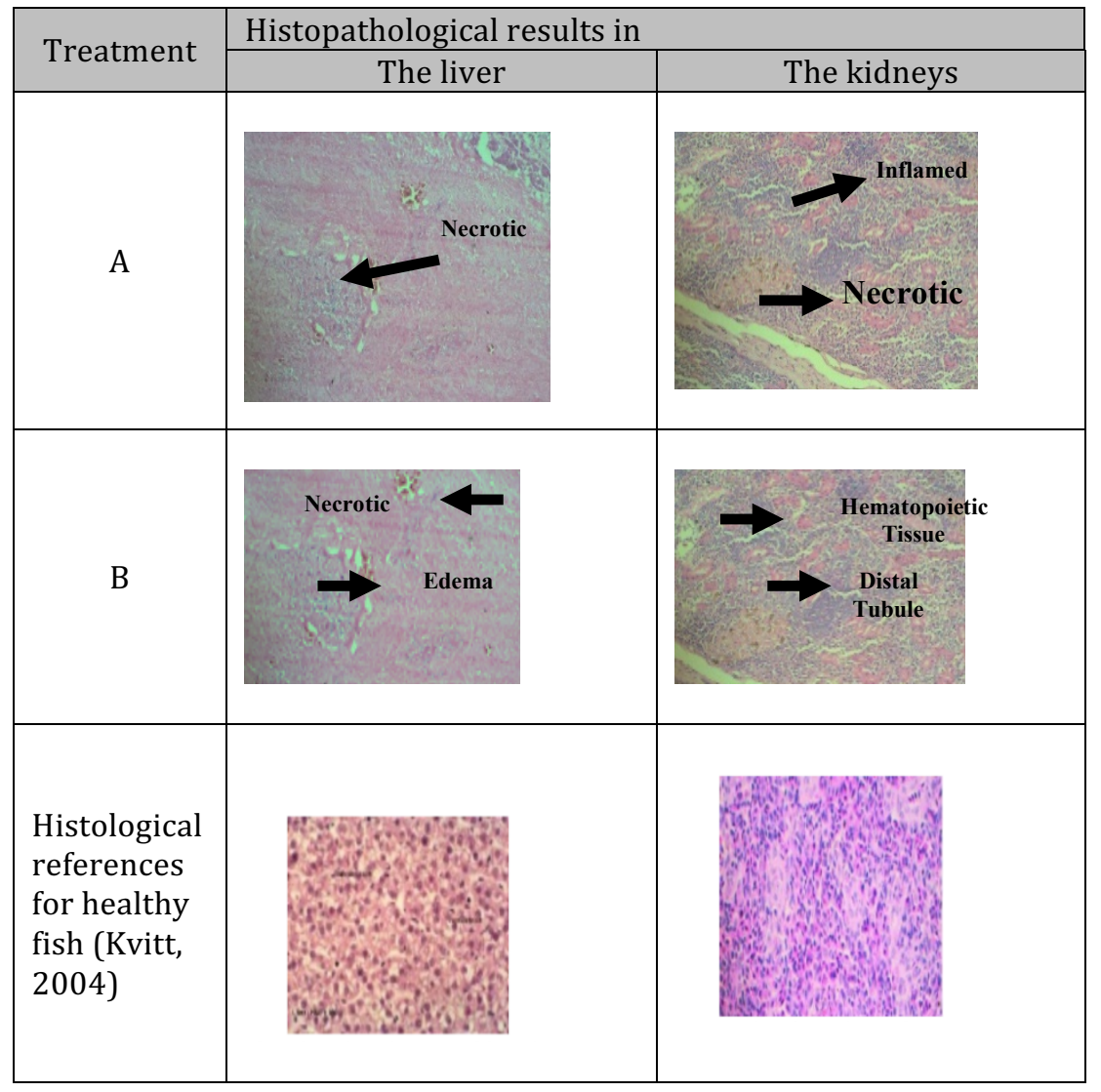

Figure 9. Histopathological test results for the liver and kidneys of the African catfish

The test results revealed that the liver and kidneys of the catfish fry, both those infected with $E$. tarda and $A$. hydrophila had yet to demonstrate a severe level of tissue damage. This was due to the fact that the bacterial infection in the liver and kidneys was still in its initial phase. 
The results for the pathological observations on the catfish liver and kidneys infected by $A$. hydrophila and E. tarda in the early stages revealed necrosis in both, showing signs of degeneration or damage to the hepatopancreas where the nuclei and cytoplasm were no longer visible. If the tissue damage were to become more severe, there would be found hemorrhages and edema. There was also the discovery of inflammation of the liver tissue accompanied by bacterial colonies (hepatitis). In addition to congestion, there was also bleeding in a number of locations and some areas were necrotized. The Melano Macrophage Center (MMC) was not found to be active.

The African catfish liver post-E. tarda infection experienced damage to the hepatopancreas in the form of necrosis $(\mathrm{N})$ which is cell death in the tissue, hemorrhage $(\mathrm{H})$ which is the leaking of blood out of the cardiovascular system. In addition to experiencing liver necrosis, the catfish infected by A. hydrophila also experienced edema and hemorrhages which could lead to liver failure. More severe damage to the liver tissues would exhibit blood plasma seepage. According to Firma et al (2002), the cause of edema is the increased intravascular hydrostatic pressure which leads to seepage of blood plasma out of the blood vessels and into the interstitial tissue. An increase in hydrostatic pressure is often found in veins and edema as a post-congestion risk.

The liver is the metabolic center of the body which produces bile as a fat emulsifier that plays an important role in food digestion (Sukenda et al., 2008). Supriadi et al., (2014) explained that necrosis is cells that exhibit a very low activity which at the end in the cell death, causing function loss in the area affected. Based on the observations, necrosis in the liver, caused by either an A. hydrophila or E. tarda infection, was still categorized as within the initial stages, characterized by the presence of tissues that still had cells whose nucleus was still visible and could be stained.

Observation results of the kidneys of the fry infected with E. tarda and A. hydrophila showed that the damage was still within the initial stages (light damage) based on the level of inflammation in the distal tubules and the necrosis found. In the kidneys of fry infected with $A$. hydrophila, there were discovered signs of degeneration in the hematopoietic tissues, whereas the kidneys infected with $E$. tarda exhibited necrosis or signs that cellular functions were disrupted. This was due to the presence of bacteria in the organ which reproduced and disrupted the cellular function. The pathological appearance of the African catfish $(C$. gariepinus) kidneys infected with $A$. hydrophila after staining with H-E (400x magnification) was atrophy, an abnormality in the number and volume of cells, or cellular shrinkage, in the distal tubules (T) and hematopoietic tissue $(\mathrm{JH})$, and the distal tubules were damaged or underwent hyaline degeneration.

According to Yardimci and Yilmaz (2011), hyaline degeneration occurs in connective tissue and the fine fibers slowly thicken and in the end become a homogeneous eosinophilic substance. Fibrocytes usually disappear and parenchymal cells experience atrophy when the connective tissue is degraded. Tissue damage in the kidneys is signified by hemorrhages and inflammation points. In some locations, necrotic areas, bacterial colonies, and active MMCs will be found.

According to Jun et al. (2010), the kidneys of Korean cyprinid loach (Misgurnus angulicaudatus) infected by $A$. hydrophila exhibited degeneration in the distal tubules and glomeruli and necrotic hematopoietic tissues. In addition, Yardimci and Yilmaz (2011) stated that pathological changes in the kidneys of Nile tilapia due to A. hydrophila infection include hemorrhages, hyperemia, and necrosis in the distal tubules. 
According to Firma et al (2002), pathogens breach the fish's immune system in order to cause disease. The fish's natural immunity enables each individual to be free from invasions from pathogens. Each individual has different immunity towards disease. Lallier et al. (1984) stated that the bacteria's ability to cause disease in fish is due to their fast reproduction in the fish's body and their ability to actively move through the bloodstream throughout the body using their flagella, causing damage to the fish's organs such as the kidneys, liver, and spleen.

The data from water quality observations can be seen in the table below:

Table 9. Data From Water Quality

\begin{tabular}{|c|c|c|c|c|c|}
\hline \multirow{2}{*}{ Treatment } & \multirow{2}{*}{ Repetition } & \multicolumn{4}{|c|}{ Water quality measurement results } \\
\hline & & DO & Temperature & $\mathrm{pH}$ & Ammonia \\
\hline \multirow[t]{3}{*}{ A } & 1 & $6.0-7.8$ & $26.6-28$ & $6.7-7.2$ & $0.03-0.06$ \\
\hline & 2 & $6.0-7.8$ & $26.6-28$ & $6.7-7.2$ & $0.03-0.06$ \\
\hline & 3 & $6.0-7.8$ & $26.6-28$ & $6.7-7.2$ & $0.03-0.06$ \\
\hline \multirow[t]{3}{*}{ B } & 1 & $6.0-7.8$ & $26.6-28$ & $6.7-7.2$ & $0.03-0.06$ \\
\hline & 2 & $6.0-7.8$ & $26.6-28$ & $6.7-7.2$ & $0.03-0.06$ \\
\hline & 3 & $6.0-7.8$ & $26.6-28$ & $6.7-7.2$ & $0.03-0.06$ \\
\hline \multirow[t]{3}{*}{ K } & 1 & $6.0-7.8$ & $26.6-28$ & $6.7-7.2$ & $0.03-0.06$ \\
\hline & 2 & $6.0-7.8$ & $26.6-28$ & $6.7-7.2$ & $0.03-0.06$ \\
\hline & 3 & $6.0-7.8$ & $26.6-28$ & $6.7-7.2$ & $0.03-0.06$ \\
\hline
\end{tabular}

The table above shows that there were no differences in the water quality measurement results between treatments $\mathrm{A}, \mathrm{B}$ and $\mathrm{K}$. Therefore, the water quality was not the cause of the test fish's mortality or SR. The control demonstrated that even in similar water conditions the mortality was low and the SR high compared to the treatments A and B. This means that there was a significant effect of another factor, the bacteria, which caused the test fish to become sick or to die.

The results of the water quality measurements during the study revealed that there was no significant change in the water quality. The results showed that the water quality was normal and suitable for the fish's needs. The water quality measurement result data can be seen in Appendix 16.

The water temperature during the study was found to be $28-29{ }^{\circ} \mathrm{C}$, in line with the statement given by Soetomo (1987) that the optimum temperature for rearing African catfish is $25-30{ }^{\circ} \mathrm{C}$. The growth of African catfish would be inhibited at temperatures less than $20{ }^{\circ} \mathrm{C}$. Mufidah et al. (2009) stated that temperatures outside of that range would decrease the fish's appetite.

Fish, like other aquatic animals, need oxygen. When the oxygen content in the water is very low, the aquatic organisms will become stressed, be susceptible to diseases and parasites, and might succumb to death. However, catfish are able to survive in aquatic environments that are 
turbid and oxygen-poor. The oxygen content suitable for fish is greater than $5 \mathrm{ppm}$, and fish will die once the oxygen content drops to $0.3 \mathrm{ppm}$. The lowest limit of oxygen tolerable to fish is $0.1 \mathrm{ppm}$.

The $\mathrm{pH}$ in water could indirectly endanger fish because a high $\mathrm{pH}$ causes ammonia poisoning and a low $\mathrm{pH}$ could have a direct effect by decreasing the organism's growth rate. The most suitable $\mathrm{pH}$ for the lives of fish ranges between 7 and 8 (Ellis in Boyd, 1979). pHs less than 6.5 and more than 9.0 would cause delays in the fish growth, while pHs of 4.0 and 11.0 would cause fish mortality. The suitable $\mathrm{pH}$ for Clarias according to Wahyuningrim et al., (2010) in Sucipto, A and Prihartono, RE (2005) is 6-9.

The data of the main results for the Survival Rate (SR) was then processed using ANOVA, the Normality test, and homogeneity test. The data was proven to be normally distributed and homogenous. The next step was variance testing using ANOVA followed by the LSD test for discovering the significant difference test results. Observation results of the fish's survival rate in this study are presented in Figure 10.

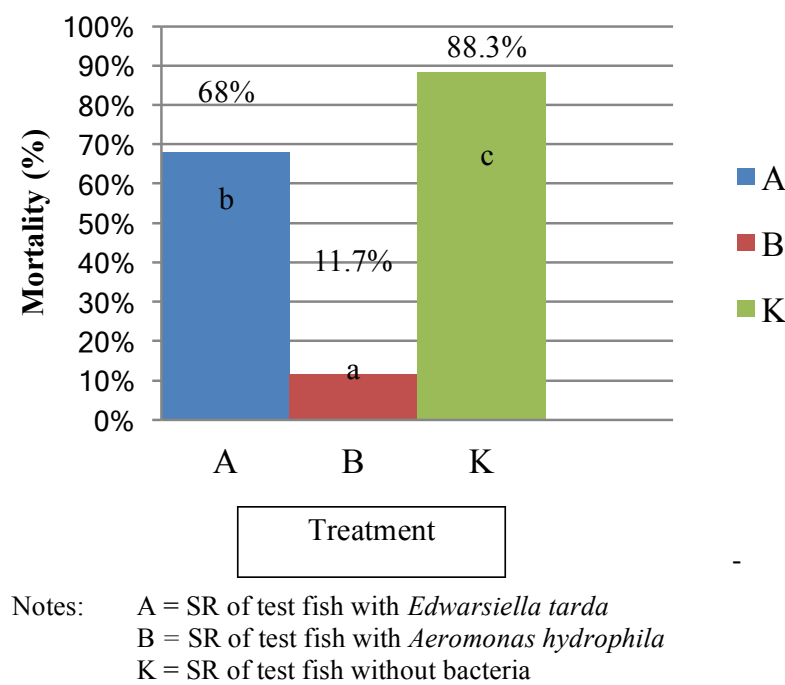

Notes: Numbers followed by different letters show there is a significant difference based on the LSD test at a level of $5 \%(\mathrm{P}<0.05)$

\section{Figure 10. The Average Survival Rate Diagram}

Based on the average difference test using ANOVA, there was a significance or p-value of 0.000 $<0.05$, so it may be concluded that there was a difference in the average survival rate (SR) between the treatment groups $\mathrm{A}, \mathrm{B}$ and $\mathrm{K}$. When viewed from the average results, the highest average survival rate (SR) was demonstrated by treatment group K or the group which was not exposed to any bacteria at 88.33, followed by the treatment group A the treatment groups exposed to Edwardsiella tarda, and the lowest survival rate was demonstrated by the treatment group B or the treatment group exposed to Aeromonas hydrophila. The data were then analyzed to discover the difference between each treatment using the LSD method.

The LSD test results revealed that the treatment groups A and B had an average difference of 20.333 and a significance of $0.004<0.05$, making it apparent that there was a significant difference between group A and group B. The treatment groups A and $\mathrm{K}$ had an average difference of 56.333 and a significance of $0.000<0.05$, making it clear that there was a significant difference between group A and group K. The treatment groups B and K had an 
average difference of 76.667 and a significance of $0.000<0.05$, making it apparent that there was a significant difference between group B and group $\mathrm{K}$. Therefore, it can be concluded that the groups with the most significant difference were groups $B$ and $K$ with the greatest difference at 76.667,

Referring to the results of the data analysis above, it can be seen that Aeromonas hydrophila is more pathogenic than Edwardsiella tarda. Treatment $\mathrm{K}$, which was the control, having no bacteria added to the feed, demonstrated a higher survival rate (SR) and lower mortality rate than treatments $\mathrm{A}$ and $\mathrm{B}$ which means that there is a significant effect of the addition of bacteria through feed on the survival rate of African catfish (Clarias gariepinus) fry. Therefore, it can be concluded that Aeromonas hydrophila is more pathogenic than Edwardsiella tarda and had a more severe effect on the survival rate of the test fish fry in this study.

\section{CONCLUSION}

Based on the results of the study about the difference of the pathogenicity of Edwardsiella tarda and Aeromonas hydrophila through feed on the survival of 4-5 cm African catfish fry, it can be concluded that the clinical signs in the test fish infected with Aeromonas hydrophila appeared more quickly than in the test fish infected with Edwardsiella tarda. The mortality rate of the test fish infected with Aeromonas hydrophila was 88\%, while the mortality rate of the test fish infected with Edwardsiella tarda was 68\%. These results demonstrate that Aeromonas hydrophila was $20 \%$ more pathogenic than the mortality of the test fish infected with Edwardsiella tarda

To increase knowledge of the difference of the pathogenicity between the bacteria, it is suggested that there be a follow-up study pertaining to the pathogenicity of these bacteria on different types of fish with an exposure technique similar to this study.

\section{References}

Angka, S.I., 2005. Kajian Penyakit Motile Aeromonad Septicemia (MAS) pada Ikan Lele Dumbo (Clarias sp); Patologi, Pencegahan dan Pengobatannya dengan Fitofarmaka. Doctoral Dissertation. Postgraduate Program, Bogor Agricultural University. Bogor.

Ariati Ria, H. Kiki and A. Yuli. 2013. Pengaruh Pemberian Tepung Kepala Udang terhadap Laju Pertumbuhan dan Konveksi pakan Benih lele (Clarias gariepinus). [Thesis]. Postgraduate Program. Padjajaran University. Bandung

Austin, B and D.A Austin 1987 a. Bacterial fish Pathogens Diseases in Farmed and Wild Fish. John Willey and Sons Ltd. England.

Barbosa, T.M., Serra, C.R., La Ragione, R.M., Woodward, M.J., \& Henriques, A.0. 2005. Screening for Bacillus isolatres in the broiler gastrointestinal tract. Applied and Enviromental Microbiology, 71 (2):968-978.

Darmayasa, I.B G. 2008. Isolasi dan Identifikasi Bakteri Pendegradasi Lipid (lemak) pada beberapa tempat pembuangan limbah dan estuary DAM Denpasar. Bumi Lestari, 8; 122-127.

Ellis, A.E. 1997. Immunization Wg Bacterial Antigens. Furunculosis. Developments in Biological Standardization in Boyd, C.E. 1979. Water Quality Management for Pond Fish Culture. International Centre for Aquaculture Experiment Station, Auburn University, Auburn

Firma, R.R Amalia, U. Sari, C. Chusbul, A. Amri, and Siregar. 2012. Detection of Edwardsiella tarda in Catfish (Clarias $s p$ ) by Fluorescent Antibody Technique (FAT). J. Akuakultur Indo. 11(1); 96-102

Hidayat, R. 2015. Deteksi Penyebaran Bakteri Aeromonas hydrophila Pada Ikan Lele Dumbo (Clarias gariepinus) di Kecamatan Medan Tuntungan. Thesis. Aquatic Resource Management Study Program. University of North Sumatra. Unpublished.

Holt, John G., Noel R. Krieg, Peter H.A. Snealth, James T. Stanley, Stanley T. Williams, 1994. Bergey's Manual of Determinative Bacteriology. Ninth Edition.

Hong, H.A., Duc, L.H., \& Cutting, S.M. 2005. The Use of Bacterial Spore Formers as Probiotics. FEMS Microbiology Review, 29, 813-835 
Kusnadi., Armen, N., \& Yudha, L. (2019). Differences Between The Pathogenicity Of Edwardsiella tarda And Aeromonas hydrophila Through Feed On The Survival Rate Of African Catfish (Clarias gariepinus) Fry. Advances in Social Sciences Research Journal, 6(1) 388-408.

Jun, J.W., Kim, J.H., Gomez, D.K., Choresca, C.H., Han, J.E., Shin, P.S., and Park, S.S. 2010. Occurrence of Tetracycline Resistant Aeromonas hydrophila in Korean Cyprinis Loach (Misqurnus anguillicaudatus). African Journal of Microbiology Research. 4(9); 849-855

Kordi, K 2004. Budidaya Ikan Kakap. Biologi dan Teknis. Semarang: Dahara Press. 101 pp.

Kurniawan, A. 2012. Penyakit Akuatik. University of Bangka Belitung (UBB) Press Pangkal Pinang

Kvitt H, A Colorni. 2004. Diseases of Aquatic Organism. Vol. 61: 67 - 73. Inter Research. www. Int.Res.com

Lallier, R., Mittal, K.R., Leblance, D., Lalonde, G., \& Olivier, G. 1984. Rapid methods for differentiation of virulent and non-virulent Aeromonas hydrophila strains.

Meidiza R., Arimbi dan Hastutiek P, 2017. Gambaran Patologi Hepar Ikan Lele Dumbo (Clarias gariepinus) yang Diinfeksi Bakteri Edwardsiella tarda. Journal Ilmiah Perikanan dan Kelautan (ISSN; 2085-58)

Meyer, F.P. \& Bullock, G.L (1973) Edwardsiella tarda, a New Pathogen of Channel Catfish Ictalurus punctatus. Applied Microbiology V (25) I. 155 - 156

Mims, C.A. 1987. The pathogenesis of infectious disease. $3^{\text {rd }}$ Ed. Department of Microbiology Guys Hospital Medical School. Academic Press, London, xi+ 342 pp.

Moat, A.G., Foster, J.W., \& Spectoor, M.P. 2002. Microbial physiology. $4^{\text {th }}$ ED. Willey \& Liss. Inc, USA, xiv+15pp

Mufidah, N.B.W., Boedi, S.R., dan Woro, H.S,. 2009. Pengkayaan Daphnia spp. dengan Viterna terhadap Kelangsungan Hidup dan Pertumbuhan Larva Ikan Lele Dumbo (Clarias gariepinus). Jurnal Ilmiah Perikanan dan Kelautan i(1):59-65

Mulia, D.S. 2010, Isolasi, Karakterisasi dan Identifikasi Bakteri Aeromonas sp. Penyebab Penyakit Motile Aeromonas Septicemia (MAS) pada Gurami. Sains Akuatik, 13(2), 9-16.

Sari, D.R., Prayitno, S.B., Sarjito, 2014. Pengaruh Perendaman Ekstrak Bawang Putih (Allium sativum) terhadap Kelulushidupan dan Histologi Ginjal Ikan Lele (Clarias bgariepinus) yang diinfeksi bakteri Edwardsiella tarda. J. of Aquac. And Tech. 3(4); 126-133

Setiowati, E., Prayitno, S.B., dan Sarjito, 2014. Pengaruh Perendaman Ekstrak Daun Jambu Biji (Psidum guajava) terhadap Kelulushidupan dan Histologi Hati Ikan Patin (Pangasius hypophthalmus) yang Diinfeksi Bakteri Edwardsiella tarda . J. of Aquaculture Management and Tech. Semarang. 3(4); 174-182

Sukenda L., Jamal, D Wahyuningrum and A, Hasan., 2008. Penggunaan Kitosan untuk Pencegahan Infeksi Aeromonas hydrophila pada Ikan Lele Dumbo Clarias SP. Jurnal Akuakultur Indonesia 7(2): 159-169

Supriadi, I,. Joko, S., Sandra, S.A. 2014. Viabilitas dan Patogenitas Edwardsiella tarda pada ikan lele dumbo (Clarias gariepinus) yang dibekukan pada suhu - 20 C. Jurnal Manajemen Perikanan dan Kelautan Vol. 1 No.1 Jakarta 13p

Todar, K., 2002, Mechanisms of Bacterial Pathogenicity Endotoxins. Todar's Online Textbook of Bacteriology. University of Wisconsin - Madison Department of Bacteriology. http://textbookofbacteriology.ne Accessed on 26 March 2007.

Wahjuningrum D., Solikhah, E.H., Budiardi T., Setiawati M., 2010. Pengendalian Infeksi Aeromonas hydrophila pada Ikan Lele Dumbo (Clarias sp) dengan Campuran Meniran (Phyllanthus niruri) dan Bawang Putih (Allium sativum) dalam Pakan. Jurnal Akuakultur Indonesia 9(2), 93-103 (2010).

Yardimci, B., dan Yilmaz, A. 2011. Pathological Findings of Experimental Aeromonas hydrophila Infection in Nila Tilapia (Oreochromis niloticus). Thesis. Department of Pathology, Faculty of Veterinary Medicine, University of Ankara. Turkey. P.58 